\title{
Synthesis of New Benzofuran-2-Carboxylic Acid Derivatives
}

\author{
M. Kowalewska, H. Kwiecień, M. Śmist, and A. Wrześniewska \\ Institute of Organic Technology, West Pomeranian University of Technology, 42 Aleja Piastów, 71-065 Szczecin, Poland \\ Correspondence should be addressed to H. Kwiecień; halina.kwiecien@zut.edu.pl
}

Received 20 June 2012; Revised 4 September 2012; Accepted 14 September 2012

Academic Editor: Aleš Imramovsky

Copyright ( 2013 M. Kowalewska et al. This is an open access article distributed under the Creative Commons Attribution License, which permits unrestricted use, distribution, and reproduction in any medium, provided the original work is properly cited.

Novel ethyl ester and methylamide of 5-[bis(2-chloroethyl)amino]-7-methoxybenzofuran-2-carboxylic acid as well as (2-hydroxy1,1-dimethylethyl)amides of 5-bromo- and 5,7-dichlorobenzofuran-2-carboxylic acid were synthesized and characterized.

\section{Introduction}

Derivatives of benzofuran-2-carboxylic acid are known for exhibiting various pharmacological activities. Such compounds were found to be selective adenosine $A_{2 A}$ receptor antagonists [1], anti-inflammatory agents [2], and local anaesthetics [3]. Variously substituted 2-benzofurancarboxylic acid derivatives show selective cytotoxicity against human cancer cell line [4]. On the other hand, benzofuran2-carboxylic acids bearing (chlorometyl)indoline or benzoyl nitrogen mustard as DNA-binding group are structural subunits of synthetic analogues of some natural antitumor agents such as CC-1065, duocarmycin, dystamycin, and netropsin [5-8]. Amide derivatives of halo-benzofuran-2carboxylic acid were found to be useful in the treatment of the diseases which are associated with the modulation of $\mathrm{H3}$ receptors [9]. Moreover, 7-piperazinylbenzofuran-2-carboxylic acid amides having halogens or methoxyl groups in benzene ring were patented as partial agonists of 5-HT receptors which should be useful in the treatment of many psychiatric disorders [10].

Many methodologies for the synthesis of benzofuran-2carboxylic acid skeleton were developed and most of them are based on the reaction of salicylaldehydes with haloacetates followed by cyclization of formylphenoxyacetic acid derivatives intermediates [11-17]. The cyclizations were usually carried out in an alcoholic solution in the presence of a basic catalyst such as sodium ethanolate [11], 1,8-diazobicyclo-[5.4.0]-7-undecane [7], potassium carbonate [12, 13], or phosphine [14]. Moreover, ethyl 5-nitrobenzofuran-2-carboxylate was prepared by cyclocondensation of 2-hydroxy-5-nitrobenzaldehyde with bromomalonic acid [18] as well as palladium catalysed carbonylative cyclization of $o$-alkynylphenols [19-21].

Most of these methods are restricted by the requirement of relatively long reaction time to obtain the expected product in low to moderate yields.

We present herein a short synthetic route to obtain halogen-substituted benzofuran-2-carboxylic acid derivatives such as (2-hydroxy-1,1-dimethylethyl)amides as well as esters and amides of benzofuran-2-carboxylic acid containing anticancer mustard type pharmacophore in their structure.

\section{Experimental Section}

2.1. General. ${ }^{1} \mathrm{H}$ and ${ }^{13} \mathrm{C}$ NMR spectra were recorded on a TM Bruker DPX $400(400 \mathrm{MHz})$ instrument, solvent $\mathrm{CDCl}_{3}$. Chemical shifts $\delta$ are given from TMS ( $0 \mathrm{ppm})$ as an internal standard for ${ }^{1} \mathrm{H}$ NMR, and $\mathrm{CDCl}_{3}(77.0 \mathrm{ppm})$ for ${ }^{13} \mathrm{C} \mathrm{NMR}$ $(100 \mathrm{MHz})$. Mass spectra were obtained on an Agilent Technologies $6890 \mathrm{~N}$ apparatus, equipped with a mass detector 5973 Network and $30 \mathrm{~m} \times 0.25 \mathrm{~mm}$ capillary column filled with a $0.25 \mu \mathrm{m}$ film of a $5 \% \mathrm{MePh}$ silicate. All melting points were determined on a Boetius apparatus and are uncorrected.

2.2. Starting Materials. Most of the reagents and solvents were purchased in a commercially available grade purity. 2-Hydroxybenzaldehyde, ethyl chloroacetate, and catalyst $(10 \% \mathrm{Pd} / \mathrm{C})$ were used without a further purification. Both dimethoxyethane (DME) and dimethylformamide (DMF) 
were dried before their use, over sodium and $4 \mathrm{~A}$ molecular sieves, respectively. 5-Bromo- $\left(\mathrm{mp} 103-105^{\circ} \mathrm{C}\right)$ and 5,7dichlorosalicylaldehyde ( $\mathrm{mp} 101-103^{\circ} \mathrm{C}$ ) were prepared by bromination or chlorination of 2-hydroxybenzaldehyde in acetic acid solution, respectively, although they are commercially available. 3-Methoxy-5-nitrobenzaldehyde (mp $140-142^{\circ} \mathrm{C}$ ) was prepared by nitration of 2-hydroxy-3methoxybenzaldehyde with $100 \%$ nitric acid in acetic acid solution, although being commercially available also. Methyl 2-bromoalkanoates: pentanoate and hexanoate were obtained according to the literature [22].

2.3. General Procedure for Synthesis of Benzofuran-2Carboxylic Acid Ethyl Esters (2a, 2b). A mixture of 2-hydroxybenzaldehyde $\mathbf{1 a}$ or $\mathbf{1 b}(0.05 \mathrm{~mol})$, ethyl chloroacetate $(0.05 \mathrm{~mol})$, anhydrous potassium carbonate $(0.075 \mathrm{~mol})$, and dry DMF $(70 \mathrm{~mL})$ was heated at $92-94^{\circ} \mathrm{C}$ with stirring for $4 \mathrm{~h}$. The solution was poured into ice water, the precipitate was filtered off, washed with water, and dried on the air. The crude ester was crystallized from methanol to give compounds $\mathbf{2} \mathbf{a}$ and $\mathbf{2} \mathbf{b}$. Compound $\mathbf{2 a}$ : 5,7-dichlorobenzofuran-2-carboxylic acid ethyl ester-yield 85\%, mp 80-81 ${ }^{\circ} \mathrm{C}$; Lit. mp. $78-79^{\circ} \mathrm{C}$ [17]. Compound 2 b: 5-bromobenzofuran-2-carboxylic acid ethyl ester-yield 78\%, mp 55-57 C; Lit. mp. 53,5-54,8 [23]. ${ }^{1} \mathrm{H}$ NMR spectra of $\mathbf{2} \mathbf{a}$ and $\mathbf{2} \mathbf{b}$ are consistent with those given in the literature $[17,23]$.

2.4. Procedure for Synthesis of 7-Methoxy-5-Nitrobenzofuran2-Carboxylic Acid Ethyl Ester (2c). A mixture of 2-hydroxy3-methoxy-5-nitrobenzaldehyde $(0.05 \mathrm{~mol})$, ethyl chloroacetate $(0.05 \mathrm{~mol})$, anhydrous potassium carbonate $(0.075 \mathrm{~mol})$, and dry DMF $(70 \mathrm{~mL})$ was heated at $92-94^{\circ} \mathrm{C}$ with stirring for $4 \mathrm{~h}$. Then the solution was poured into ice water, the precipitate was filtered off, washed with water, and dried on the air. The crude ester was crystallized from methanol to give 2-(2-formy-6-methoxy-4-nitrophenoxy) acetic acidethyl ester (4, mp $107-109^{\circ} \mathrm{C}$, Lit. mp. $107-109^{\circ} \mathrm{C}$ [7]). Next, a mixture of dried ester, anhydrous potassium carbonate $(0.065 \mathrm{~mol})$, and dry DMF $(70 \mathrm{~mL})$ was heated at $92-94^{\circ} \mathrm{C}$ with stirring for $4 \mathrm{~h}$. After that the solution was poured into ice water, the precipitate was filtered off, washed with water, and dried on the air to give $2 \mathrm{c}$. Compound $2 \mathrm{c}$ : yield-73\%, mp. $162-164^{\circ} \mathrm{C}$, Lit. mp. 161-162 [7]. GC/MS $(\tau=21.41 \mathrm{~min}), \mathrm{MS} m / z(\%)=265\left(\mathrm{M}^{+}, 100\right), 250(1), 237$ (9), 219 (26), 204 (9), 191 (13), 174 (8), 161 (2), 147 (3), 133 (2), 120 (4), 103 (3), 89 (4), 75 (5), and 62 (2).

2.5. General Procedure for Synthesis of Benzofuran-2Carboxylic Acid (2-Hydroxy-1,1-Dimethylethyl)-Amides $(3 \mathbf{a}, 3 \mathbf{b})$. A mixture of benzofuran-2-carboxylic acid ethyl esters $\mathbf{2 a}$ or $\mathbf{2 b}(0.03 \mathrm{~mol}), 2$-amino-2-methylpropan-1-ol $(0.045 \mathrm{~mol})$, ammonium chloride $(0.05 \mathrm{~g})$, and methanol $(30 \mathrm{~mL})$ was heated at $65-67^{\circ} \mathrm{C}$ with stirring for $16 \mathrm{~h}$. Then the solution was poured into water, the precipitate was filtered off, washed with water, and dried on the air. The crude amide was crystallized from methanol to give compounds $\mathbf{3 a}$ or 3b. Compound 3a: 5,7-dichlorobenzofuran-2-carboxylic acid (2-hydroxy-1,1-dimethylethyl)amide-yield 62\%, mp 129-130 ${ }^{\circ} \mathrm{C} .{ }^{1} \mathrm{H}$ NMR $\delta 7.54(\mathrm{~d}, J=1.3 \mathrm{~Hz}, 1 \mathrm{H}, \mathrm{Ar}), 7.41$ $(\mathrm{d}, J=3.1 \mathrm{~Hz}, 2 \mathrm{H}, \mathrm{Ar}), 6.69(\mathrm{~s}, 1 \mathrm{H}, \mathrm{NH}), 4.14(\mathrm{~s}, 1 \mathrm{H}$, $\mathrm{OH}), 3.75\left(\mathrm{~d}, \mathrm{~J}=5.7 \mathrm{~Hz}, 2 \mathrm{H}, \mathrm{CH}_{2}\right), 1.47\left(\mathrm{~s}, 6 \mathrm{H}, \mathrm{CH}_{3}\right)$; Anal. Calcd for $\mathrm{C}_{13} \mathrm{H}_{13} \mathrm{Cl}_{2} \mathrm{NO}_{3}$ (302.15): C, 51.68; $\mathrm{H}, 4.34$; $\mathrm{N}, 4.64 ; \mathrm{Cl}, 23.47$. Found: C, 51.56; H, 4.43; N, 4.56; Cl, 23.25. Compound 3b: 5-bromobenzofuran-2-carboxylic acid (2-hydroxy-1,1-dimethylethyl)amide-yield 57\%, mp 147.5-148.5 ${ }^{\circ} \mathrm{C} .{ }^{1} \mathrm{H}$ NMR $\delta 7.81$ (d, $\left.J=1.8 \mathrm{~Hz}, 1 \mathrm{H}, \mathrm{Ar}\right), 7.50$ (s, $1 \mathrm{H}, \mathrm{Ar}), 7.39(\mathrm{~d}, J=3.1 \mathrm{~Hz}, 2 \mathrm{H}, \mathrm{Ar}), 6.66(\mathrm{~s}, 1 \mathrm{H}, \mathrm{NH})$, 4.18 (s, 1H, OH), $3.74\left(\mathrm{~d}, J=6.3 \mathrm{~Hz}, 2 \mathrm{H}, \mathrm{CH}_{2}\right), 1.45(\mathrm{~s}, 6 \mathrm{H}$, $\mathrm{CH}_{3}$ ); Anal. Calcd for $\mathrm{C}_{13} \mathrm{H}_{14} \mathrm{BrNO}_{3}$ (312.16): C, 50.02; $\mathrm{H}$, 4.52; N, 4.49; Br, 25.60. Found: C, 49.89; H, 4.63; N, 4.33; Br, 25.69 .

2.6. Procedure for Catalytic Reduction of 7-Methoxy-5Nitrobenzofuran-2-Carboxylic Acid Ethyl Ester (2c). A mixture of $2 \mathrm{c}(0.5 \mathrm{~g}, 1.9 \mathrm{mmol})$ and $10 \% \mathrm{Pd} / \mathrm{C}(0.065 \mathrm{~g})$ in methanol $(30 \mathrm{~mL})$ and dimethoxyethane $(10 \mathrm{~mL})$ was stirred under hydrogen atmosphere for $3.5 \mathrm{~h}$. The $\mathrm{Pd} / \mathrm{C}$ catalyst was removed and the filtrate concentrated in vacuo. The crude product was crystallized from a mixture of chloroform and $n$-hexane (1:3) to afford 5-amino-7-methoxybenzofuran-2carboxylic acid ethyl ester (5) as brown crystals. Compound 5: yield-91\%, mp 107-109 ${ }^{\circ} \mathrm{C} .{ }^{1} \mathrm{H}$ NMR $\delta 7.35$ (s, 1H, Ar), 6.48 (s, 1H, Ar), 6.36 (s, 1H, Ar), $4.41(\mathrm{q}, J=7.0 \mathrm{~Hz}, 2 \mathrm{H}$, $\left.\mathrm{CH}_{2}\right), 3.95\left(\mathrm{~s}, 3 \mathrm{H}, \mathrm{OCH}_{3}\right), 3.62\left(\mathrm{~s}, 2 \mathrm{H}, \mathrm{NH}_{2}\right), 1.40(\mathrm{t}, J=$ $\left.7.0 \mathrm{~Hz}, 3 \mathrm{H}, \mathrm{CH}_{3}\right) ;{ }^{13} \mathrm{C} \mathrm{NMR} \delta 159.5,146.1,146.1,143.8$, $140.2,129.1,113.6,100.0,97.8,61.3,55.9,14.4$; GC/MS $(\tau=$ $20.98 \mathrm{~min}), \mathrm{MS} m / z(\%)=235\left(\mathrm{M}^{+}, 100\right), 207$ (99), 190 (10), 177 (4), 164 (35), 148 (1), 134 (5), 120 (4), 104 (5), 91 (4), 77 (3), 63 (2), 50 (1). Anal. Calcd for $\mathrm{C}_{12} \mathrm{H}_{13} \mathrm{NO}_{4}$ (235.24): C, 61.27; H, 5.57; N, 5.95. Found: C, 61.21; H, 5.69; N, 5.86.

\subsection{Procedure for Synthesis of 5-Amino-7-Methoxybenzo-fu-} ran-2-Carboxylic Acid Methyl Amide (6). A mixture of 5amino-7-methoxybenzofuran-2-carboxylic acid ethyl ester 5 $(2.8 \mathrm{mmol})$, solution of $\mathrm{N}$-methylamine in methanol $(24 \mathrm{~mL})$, ammonium chloride $(0.05 \mathrm{~g})$, and methanol $(30 \mathrm{~mL})$ was left for 48 hours at room temperature. Then the solution was evaporated. The crude amide was crystallized from a mixture of chloroform and $n$-hexane $(1: 3)$ to give product 6. Compound 6: yield-98\%, mp $156-160^{\circ} \mathrm{C} .{ }^{1} \mathrm{H}$ NMR $\delta$ 7.29 (s, 1H, Ar), 6.90 (s, 1H, NH), 6.47 (s, 1H, Ar), 6.33 (s, $1 \mathrm{H}, \mathrm{Ar}), 3.92\left(\mathrm{~s}, 3 \mathrm{H}, \mathrm{OCH}_{3}\right), 3.72-3.47\left(\mathrm{~m}, 2 \mathrm{H}, \mathrm{NH}_{2}\right), 2.97$ $\left(\mathrm{d}, J=4.7 \mathrm{~Hz}, 3 \mathrm{H}, \mathrm{CH}_{3}\right) ;{ }^{13} \mathrm{C} \mathrm{NMR} \delta 159.6,149.2,145.5$, $143.8,138.8,129.7,110.1,99.1,98.3,55.9,25.9$; GC/MS $(\tau=$ $22.67 \mathrm{~min}), \mathrm{MS} m / z(\%)=220\left(\mathrm{M}^{+}, 100\right), 204(1), 190$ (24), 177 (7), 162 (12), 148 (3), 134 (9), 120 (7), 104 (5), 91 (4), 77 (3), 58 (2). Anal. Calcd for $\mathrm{C}_{11} \mathrm{H}_{12} \mathrm{~N}_{2} \mathrm{O}_{3}$ (220.22): C, 59.99; H, 5.49; N, 12.72. Found: C, 59.90; H, 5.57; N, 12.57 .

2.8. General Procedure for Synthesis of 5-[Bis(2-Hydroxyethyl) Amino]-7-Methoxybenzofuran-2-Carboxylic Acid Derivatives $(7 \mathbf{a}, 7 \mathbf{b})$. To a solution of amino derivative 5 or $\mathbf{6}(1.9 \mathrm{mmol})$ in methanol $(10 \mathrm{~mL})$, cooled to $7^{\circ} \mathrm{C}$, cold ethylene oxide $(1 \mathrm{~mL})$ was added. The reaction flask was sealed and was left 
in refrigerator at $6-7^{\circ} \mathrm{C}$ for two weeks. Methanol and excess of ethylene oxide were removed by evaporation and the crude product was crystallized from chloroform and $n$-hexane $(1: 3)$ to give product $7 \mathbf{a}$ or $7 \mathbf{b}$. Compound $7 \mathbf{a}$ : yield $-50 \%$, semisolid product. ${ }^{1} \mathrm{H}$ NMR $\delta 7.36(\mathrm{~d}, J=1.7 \mathrm{~Hz}, 1 \mathrm{H}, \mathrm{Ar})$, 6.51-6.33 (m, 2H, Ar), $4.42\left(\mathrm{q}, J=7.1 \mathrm{~Hz}, 2 \mathrm{H}, \mathrm{CH}_{2}\right), 3.99$ (s, 3H, $\left.\mathrm{OCH}_{3}\right), 3.95(\mathrm{~s}, 1 \mathrm{H}, \mathrm{OH}), 3.89-3.84\left(\mathrm{~m}, 4 \mathrm{H}, \mathrm{CH}_{2}\right)$, 3.56-3.54 (m, 4H, $\left.\mathrm{CH}_{2}\right), 3.31(\mathrm{t}, J=5.1 \mathrm{~Hz}, 1 \mathrm{H}, \mathrm{OH}), 1.41$ $\left(\mathrm{t}, J=7.3 \mathrm{~Hz}, 3 \mathrm{H}, \mathrm{CH}_{3}\right) ;{ }^{13} \mathrm{C} \mathrm{NMR} \delta 158.9,146.5,146.2$, $143.6,140.2,130.9,114.1,99.7,98.5,60.9,59.2,56.9,56.3$, 14.2; GC/MS $(\tau=26.53 \mathrm{~min}), \mathrm{MS} m / z(\%)=323\left(\mathrm{M}^{+}, 10\right)$, 305 (1), 292 (100), 278 (2), 264 (5), 248 (9), 233 (1), 220 (9), 202 (4), 177 (1), 146 (1), 89 (1). Anal. Calcd for $\mathrm{C}_{16} \mathrm{H}_{21} \mathrm{NO}_{6}$ (323.34): C, 59.43; H, 6.55; N, 4.33. Found: C, 59.35; H, $6.61 ; \mathrm{N}, 4.21$. Compound $7 \mathbf{b}$ : yield-67\%, mp $132-135^{\circ} \mathrm{C} .{ }^{1} \mathrm{H}$ NMR $\delta 8.30(\mathrm{t}, J=4.5 \mathrm{~Hz}, 1 \mathrm{H}, \mathrm{Ar}), 7.08(\mathrm{~d}, J=2.0 \mathrm{~Hz}, 1 \mathrm{H}$, $\mathrm{NH}), 6.32(\mathrm{~d}, J=2.1 \mathrm{~Hz}, 1 \mathrm{H}, \mathrm{Ar}), 6.26(\mathrm{~d}, J=2.1 \mathrm{~Hz}, 1 \mathrm{H}$, Ar), 4.62-4.60 (m, 2H, OH), 3.75 (s, 3H, $\left.\mathrm{OCH}_{3}\right), 3.41-3.18$ $\left(\mathrm{m}, 8 \mathrm{H}, \mathrm{CH}_{2}\right), 2.60\left(\mathrm{~d}, J=4.7 \mathrm{~Hz}, 3 \mathrm{H}, \mathrm{CH}_{3}\right) ;{ }^{13} \mathrm{C} \mathrm{NMR} \delta$ $160.1,149.2$, 144.5, 143.7, 138.9, 129.7, 110.0, 99.1, 98.5, 56.1, $54.9,40.5,25.8$; GC/MS $(\tau=27.24 \mathrm{~min}), \mathrm{MS} \mathrm{m} / z(\%)=$ $308\left(\mathrm{M}^{+}, 15\right), 277$ (100), 257 (1), 233 (24), 202 (10), $176(8)$, 148 (5), 117 (4), 89 (6), 58 (15). Anal. Calcd for $\mathrm{C}_{15} \mathrm{H}_{20} \mathrm{~N}_{2} \mathrm{O}_{5}$ (308.33): C, 58.43; H, 6.54; N, 9.09. Found: C, 58.31; H, 6.59; N, 8.94.

\subsection{General Procedure for Synthesis of 5-[Bis(2-Chloroethyl)} Amino]-7-Methoxybenzofuran-2-Carboxylic Acid Derivatives $(\mathbf{8 a}, \mathbf{8 b})$. To a solution of compound $\mathbf{8 a}$ or $\mathbf{8 b}(0.6 \mathrm{mmol})$ in dichloromethane $(50 \mathrm{~mL})$ thionyl chloride $(0.8 \mathrm{~mL})$ was added. The reaction flask was sealed and was left at room temperature for $24 \mathrm{~h}$. Dichloromethane and excess of thionyl chloride were removed by evaporation and the crude product was washed with $n$-hexane and next crystallized from the same solvent to give product $\mathbf{8 a}$ or $\mathbf{8 b}$. Compund $\mathbf{8 a}$ : yield-47\%, oil product. ${ }^{1} \mathrm{H}$ NMR $\delta 7.48$ (s, 1H, Ar), 6.40 (s, 1H, Ar), 6.01 (s, 1H, Ar), 4.21 (q, J = 7.1 Hz, $2 \mathrm{H}, \mathrm{CH}_{2}$ ), $3.79\left(\mathrm{~s}, 3 \mathrm{H}, \mathrm{OCH}_{3}\right), 3.61-3.43\left(\mathrm{~m}, 8 \mathrm{H}, \mathrm{CH}_{2}\right), 1.39(\mathrm{t}, J=7.1$, $\left.3 \mathrm{H}, \mathrm{CH}_{3}\right)$; GC/MS ( $\left.\tau=26.00 \mathrm{~min}\right), \mathrm{MS} m / z(\%)=360\left(\mathrm{M}^{+}\right.$, 17), 324 (1), 310 (100), 282 (9), 247 (3), 233 (2), 219 (4), 202 (3), 177 (1), 130 (1), 116 (1), 89 (1), 63 (1). Anal. Calcd for $\mathrm{C}_{16} \mathrm{H}_{19} \mathrm{Cl}_{2} \mathrm{NO}_{4}$ (360.23): C, 53.35; H, 5.32; N, 3.89; Cl, 19.68 . Found: C, 53.17; H, 5.41; N, 3.82; Cl, 19.49. Compound $\mathbf{8 b}$ : yield-49\%, mp 80-82 ${ }^{\circ} \mathrm{C} .{ }^{1} \mathrm{H}$ NMR $\delta 7.25$ (s, $1 \mathrm{H}, \mathrm{Ar}$ ), 6.70 (s, 1H, NH), 6.40 (s, 1H, Ar), 6.34 (s, 1H, Ar), 3.92 (s, 3H, $\left.\mathrm{OCH}_{3}\right), 3.64-3.44\left(\mathrm{~m}, 8 \mathrm{H}, \mathrm{CH}_{2}\right), 2.93\left(\mathrm{~s}, 3 \mathrm{H}, \mathrm{CH}_{3}\right) ;{ }^{13} \mathrm{C} \mathrm{NMR}$ $\delta$ 159.4, 149.4, 144.3, 140.1, 132.5, 129.9,110.3, 98.0, 97.4, $56.1,54.6,40.8,25.9 ; \mathrm{GC} / \mathrm{MS}(\tau=27.38 \mathrm{~min}), \mathrm{MS} m / z(\%)=$ $344\left(\mathrm{M}^{+}, 26\right), 295$ (100), 281 (1), 295 (2), $246(1), 232$ (10), 218 (5), 202 (8), 188 (2), 175 (4), 161 (2), 147 (4), 130 (2), 116 (2), 103 (2), 89 (2), 76 (1), 58 (3). Anal. Calcd for $\mathrm{C}_{15} \mathrm{H}_{18} \mathrm{Cl}_{2} \mathrm{~N}_{2} \mathrm{O}_{3}$ (345.22): C, 52.19; H, 5.26; N, 8.11; Cl, 20.54. Found: C, 52.10; $\mathrm{H}, 5.37 ; \mathrm{N}, 8.01 ; \mathrm{Cl}, 20.37$.

\section{Results and Discussion}

In order to obtain 5-nitro and halo-substituted benzofurnan2-carboxylic acid derivatives we have developed a method of synthesis proceeding via corresponding ethyl 2-formylphenoxy acetates as the intermediates. According to the literature reports ethyl 2-formylphenoxyacetate acid was obtained by $O$-alkylation of salicylaldehyde with ethyl bromoacetate carried out in acetone or dimethylformamide under heating conditions for 20 hours $[24,25]$. The condensation was also carried out in acetone in the presence of tripotassium phosphate but this process was proven to be slow [26]. Moreover, the reaction of 2-hydroxy-5-nitrobenzaldehydes with ethyl bromoacetate was also reported to be a slow process lasting for 36 hours [12].

We have previously observed that the reaction of salicylaldehyde with ethyl chloroacetate, carried out in DMF solution and with the use of potassium carbonate as a basic dehydrating agent, led to a mixture of two esters: ethyl 2-formylphenoxyacetate and ethyl benzofuran-2carboxylate in ratio 1:1 [12]. In the present research we have found that the reactions of 5-bromo- or 3,5dichloro-2-hydroxybenzaldehyde with ethyl chloroacetate, carried out in DMF solution in the presence of 1.5 molar excess of anhydrous potassium carbonate at $92-94^{\circ} \mathrm{C}$ for 4 hours, lead only to the corresponding cyclic esters: ethyl 5-bromo- or 5,7-dichlorobenzofuran-2-carboxylate $(\mathbf{2 a}, \mathbf{2} \mathbf{b})$ (Scheme 1 ). In both cases the products were obtained in high yields.

The obtained ethyl halo-benzofuran-2-carboxylates (2a and $\mathbf{2 b}$ ) were next subjected to the reaction with 2-amino-2methylpropan-1-ol in the presence of ammonium chloride. When this process was carried out in boiling methanol for 16 hours the target benzofuran-2-carboxylic acid (2-hydroxy1,1-dimethylethyl)amides ( $3 \mathbf{a}$ and $\mathbf{3 b}$ ) were obtained in moderate yields.

On the other hand, the reaction of 2-hydroxy-5-nitro3-methoxybenzaldehyde (1c) with ethyl chloroacetate performed in the same conditions as for synthesis of $\mathbf{2 a}$ (DMF, $\mathrm{K}_{2} \mathrm{CO}_{3}$ ) afforded only ethyl 2-formyl-6-methoxy-4-nitrophenoxyacetate (4). An attempt to obtain the cyclic product by one-pot synthesis failed, despite longer reaction time (10 hours) and the use of more than double molar excess of $\mathrm{K}_{2} \mathrm{CO}_{3}$.

However, when dried ethyl 2-formyl-6-methoxy-4nitrophenoxyacetate (4) underwent 4-hour cyclization in DMF with 1.3 molar excess of anhydrous potassium carbonate at $92-94^{\circ} \mathrm{C}$ the desired ethyl 7-methoxy-5nitrobenzofuran-2-carboxylate (2c) was obtained in good yield $(73 \%)$ (Scheme 2). These conditions were established according to the results of several trials of this reaction in which the reaction time and the molar ratio of potassium carbonate to the ester were varied (Table 1).

Cyclization of 2-formylphenoxyacetic acid ethyl ester to the benzofuran derivative is based on base catalyzed intramolecular aldolization of formyl ester via formation of carbiol and next elimination of water (Scheme 3 ). The presence of halogens as donors of electrons favors this reaction. On the other hand, strongly electrophilic nitro group lower the activity of the carbonyl group and because of that it was not possible to obtain the suitable ester of benzofuran-2carboxylic acid in a one-step process. The desired product $2 \mathrm{c}$ could be only obtained starting from previously isolated and 
TABLE 1: Cyclization of ethyl 6-methoxy-4-nitro-2-formylphenoxyacetate (4).

\begin{tabular}{|c|c|c|c|}
\hline Trial & $\begin{array}{c}\text { Molar ratio } \\
\text { Ester } 4 / \mathrm{K}_{2} \mathrm{CO}_{3}\end{array}$ & Reaction time (h) & $\begin{array}{c}\text { Product 2c } \\
\text { Yield }(\%)^{*}\end{array}$ \\
\hline 1 & $1: 1$ & 3 & - \\
\hline 2 & $1: 1$ & 3.5 & 52 \\
\hline 3 & $1: 1$ & 4 & 60 \\
\hline 4 & $1: 1.3$ & 3 & 59 \\
\hline 5 & $1: 1.3$ & 3.5 & 64 \\
\hline 6 & $1: 1.3$ & 4 & 73 \\
\hline
\end{tabular}

${ }^{*}$ The yield was calculated relative to the starting ester 4.

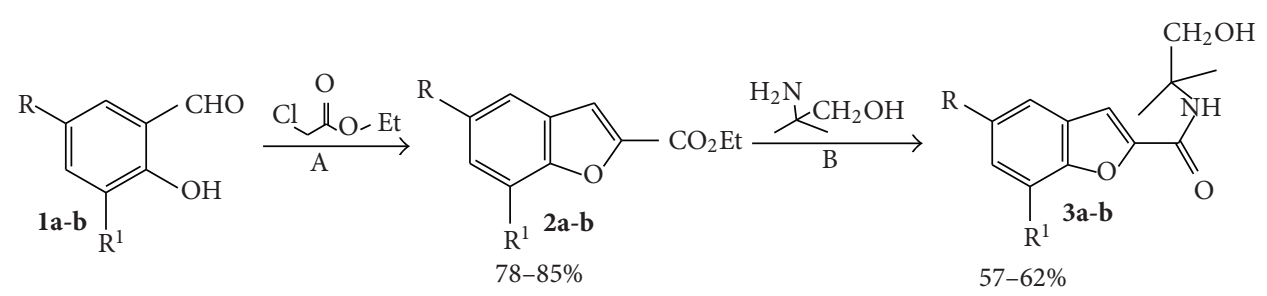

1a, 2a, 3a: $\mathrm{R}=\mathrm{R}^{1}=\mathrm{Cl}$

$\mathbf{1 b}, \mathbf{2 b}, \mathbf{3 b}: \mathrm{R}=\mathrm{Br}, \mathrm{R}^{1}=\mathrm{H}$

SCHeme 1: A: $\mathrm{K}_{2} \mathrm{CO}_{3}$ (1.5 equiv.), DMF, 92-94 ${ }^{\circ} \mathrm{C}, 4$ h; $\mathrm{B}: \mathrm{NH}_{4} \mathrm{Cl}, \mathrm{MeOH}$, r.t., 16 h.

dried ester 4 by heating in DMF in the presence of anhydrous $\mathrm{K}_{2} \mathrm{CO}_{3}$ as a base.

The obtained 7-methoxy-5-nitrobenzofuran-2-carboxylate (2c) was subsequently reduced to the corresponding amine (5). The reduction was carried out in methanoldimethoxyethane mixture at room temperature under a hydrogen stream, with the use of $10 \%$ palladium on activated coal as a catalyst. In order to obtain the desired product in satisfactory yield three attempts of reduction were made. The reduction was performed with different weight ratio of nitrobenzofuran to the catalyst, that is, $1: 0.1$ or $1: 0.13$, for 3.5 or 4 hours. Progress of the reaction was monitored by GC/MS analysis of periodically taken samples. When the reduction was finished the reaction mixture was left for 24 hours. The catalyst was filtered off and the solvent was evaporated, affording the crude product which was analyzed by GC/MS and crystallized. The best result of the reduction was achieved when the reaction was carried out at room temperature for 3.5 hours, using a weight ratio of ethyl 7-methoxy-5-nitrobenzofuran-2-carboxylate to the catalyst of $1: 0.13$. In these conditions the crude ethyl 5-amino-7methoxybenzofuran-2-carboxylate (5) was obtained in $91 \%$ yield.

Next, 5-amino-7-methoxybenzofuran-2-carboxylate (5) underwent aminolysis with methyl amine to give the corresponding amide (6). This reaction was carried out in methanol, in the presence of ammonium chloride at room temperature for 48 hours. The crude product was crystallized from chloroform and $n$-hexane $(1: 3)$ and 5-amino-7methoxy-2-benzofuranocarboxylic acid $\mathrm{N}$-methyl amide (6) was obtained as a brown solid in $98 \%$ yield.

In the next step the amino compounds (5 and 6) were transformed into corresponding bis(2-chloroethyl)amino derivatives (8a and $\mathbf{8 b}$ ) with the use of a two-step strategy: N-hydroxyalkylation with ethylene oxide followed by chlorination with thionyl chloride (Scheme 1). When Nhydroxyalkylation of ethyl 5-amino-7-methoxybenzofuran2-carboxylate (5) with ethylene oxide was performed with 5 -fold molar excess of ethylene oxide in methanol and the reaction mixture was left at $6-7^{\circ} \mathrm{C}$ for two weeks, the crude product consisted of two compounds, that is, the desired ethyl 5-[bis(2-hydroxyethyl)amino]-7-methoxybenzofuran2-carboxylate (60\%) and ethyl 5-[mono-(2-hydroxyethyl) amino]-7-methoxybenzofuran-2-carboxylate (40\%). Therefore, in the next attempt a larger, 10-fold molar excess of ethylene oxide was employed while the other conditions of the reaction remain unchanged. The product was analyzed by CG/MS and it turned out that only the target ethyl 5-[bis(2-hydroxyethyl)amino]-7-methoxybenzofuran2-carboxylate (7a) was obtained. Next, the reaction of amine 6 with ethylene oxide was carried out in the same conditions to give derivative $\mathbf{7 b}$ in good yield.

Bis(2-hydroxyethyl)amino derivatives $7 \mathbf{a}$ and $\mathbf{7 b}$ were next subjected to the reaction with thionyl chloride. To obtain 


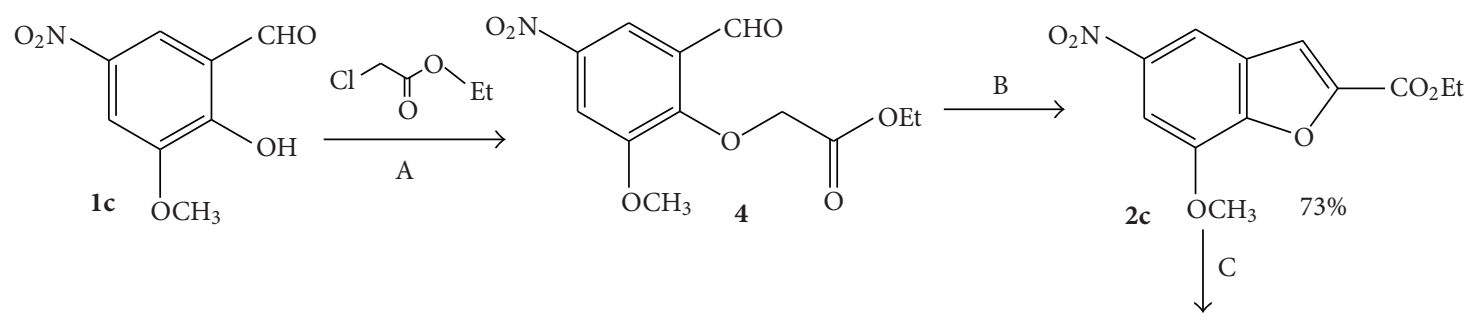

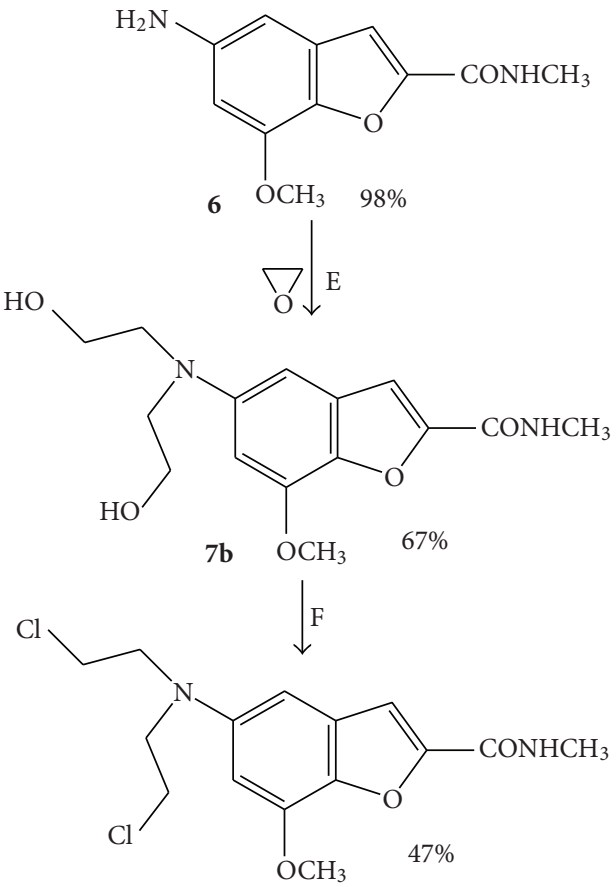

$8 b$

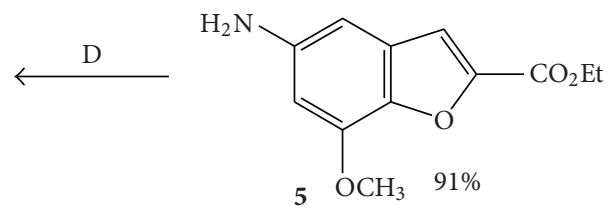<smiles>CCOC(=O)c1cc2cc(N(CCO)CCO)cc(OC)c2o1</smiles>

$7 \mathrm{a}$<smiles>CCOC(=O)c1cc2cc(N(CCCl)CCCl)cc(OC)c2o1</smiles>

$8 a$

Scheme 2: A: $\mathrm{K}_{2} \mathrm{CO}_{3}$ (1.5 equiv.), DMF, 92-94 ${ }^{\circ} \mathrm{C}, 4$ h; B: $\mathrm{K}_{2} \mathrm{CO}_{3}$ (1.3 equiv.), DMF, 92-94 ${ }^{\circ} \mathrm{C} ; \mathrm{C}_{2} \mathrm{H}_{2}, \mathrm{Pd} / \mathrm{C}, \mathrm{CH}_{3} \mathrm{OH}, \mathrm{DME}, 3.5$ h; D: $\mathrm{NH}_{2} \mathrm{CH}_{3}$, $\mathrm{NH}_{4} \mathrm{Cl}, \mathrm{CH}_{3} \mathrm{OH}, 48$ h; E: $\mathrm{CH}_{3} \mathrm{OH}, 6-7^{\circ} \mathrm{C}, 2$ weeks; F: $\mathrm{SOCl}_{2}, \mathrm{CH}_{2} \mathrm{Cl}_{2}, 24$ h.

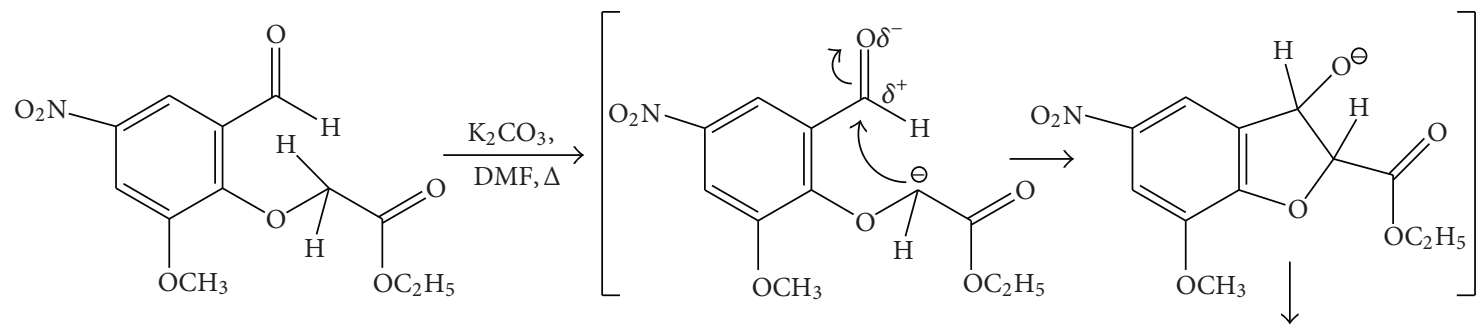<smiles>CCOC(=O)C1Oc2c(OC)cc([N+](=O)[O-])cc2C1O</smiles>

SCHEME 3 
the desired products $\mathbf{8} \mathbf{a}$ and $\mathbf{8} \mathbf{b}$ in good yields several attempts to this reaction were done using benzene or methylene chloride as solvents and changing reaction temperature and the time. The desired products $\mathbf{8} \mathbf{a}$ and $\mathbf{8 b}$ were finally obtained in the highest yields of $47 \%$ and $50 \%$, respectively, when the reagents were left in methylene chloride at room temperature for 24 hours.

\section{Conclusion}

Herein, we have described the efficient synthesis of 5-bromoand 5,7-dichlorobenzofuran-2-carboxylic acid (2-hydroxy1,1-dimethylethyl)amides and 5-[bis(2-chloroethyl)amino]7-methoxy-benzofuran-2-carboxylic acid ethyl esters and methylamides starting from commercially available materials. The presented method can be easily applied in a largescale synthesis and the obtained compounds can be utilized for further pharmacological applications.

\section{Conflict of Interests}

The authors declare that they do not have a direct financial relation with the commercial identity mentioned in this paper that might lead to a conflict of interests.

\section{References}

[1] O. Saku, M. Saki, M. Kurokawa, K. Ikeda, T. Takizawa, and N. Uesaka, "Synthetic studies on selective adenosine $\mathrm{A}_{2 \mathrm{~A}}$ receptor antagonists: synthesis and structure-activity relationships of novel benzofuran derivatives," Bioorganic and Medicinal Chemistry Letters, vol. 20, no. 3, pp. 1090-1093, 2010.

[2] B. Y. Mane, Y. S. Agasimundin, and B. Shivakumar, "Synthesis of benzofuran analogs of fenamates as non steroidal antiinflammatory agents," Indian Journal of Chemistry, vol. 49, no. 2, pp. 264-269, 2010.

[3] J. Kossakowski and T. Zawadowski, "Synthesis of some amides of benzofurane-2-carboxylic and benzofurane-3-carboxylic acids with potential antidepressant activity," Acta Poloniae Pharmaceutica, vol. 44, no. 6, pp. 497-502, 1987.

[4] J. Kossakowski, K. Ostrowska, E. Hejchman, and I. Wolska, "Synthesis and structural characterization of derivatives of 2and 3-benzo[b]furan carboxylic acids with potential cytotoxic activity," Farmaco, vol. 60, no. 6-7, pp. 519-527, 2005.

[5] P. G. Baraldi, R. Romagnoli, I. Beria et al., "Synthesis and antitumor activity of new benzoheterocyclic derivatives of distamycin A," Journal of Medicinal Chemistry, vol. 43, no. 14, pp. 2675-2684, 2000.

[6] Y. Wang, L. Li, W. Ye et al., "CC-1065 analogues bearing different DNA-binding subunits: synthesis, antitumor activity, and preliminary toxicity study," Journal of Medicinal Chemistry, vol. 46, no. 4, pp. 634-637, 2003.

[7] V. F. Patel, S. L. Andis, J. K. Enkema et al., "Total synthesis of seco (+)- and ent-(-)-oxaduocarmycin SA: construction of the (chloromethyl)indoline alkylating subunit by a novel intramolecular aryl radical cyclization onto a vinyl chloride," Journal of Organic Chemistry, vol. 62, no. 25, pp. 8868-8874, 1997.

[8] P. G. Baraldi, R. Romagnoli, N. Bianchi, and R. Gambari, "Benzoyl nitrogen mustard derivatives of benzoheterocyclic analogues of netropsin: synthesis and biological activity, Bioorganic and Medicinal Chemistry, vol. 11, no. 11, pp. 2381-2388, 2003.

[9] P. Mohr, M. Nettekoven, J. Plancher et al., "Benzofuran and benzothiophene-2-carboxylic acids amide derivatives," US Pat. 0029976 A1, 2009.

[10] J. H. Andersson, H. Gybäck, A. Johansson et al., "2-Carboxamide-7-piperazinyl-benzofuran derivatives 774," US Pat. 0331341 A1, 2010.

[11] H. Dumont and S. Kostanecki, "Zur kenntnis der cumarongruppe," Chemische Berichte, vol. 42, no. 1, pp. 911-915, 1909.

[12] H. Kwiecień, "Synthesis and properties of new 2-alkyl-1,4benzoxazepine derivatives. Part III. Synthesis and cyclization of 2-(2-carboxyphenoxy)alkanamides," Polish Journal of Chemistry, vol. 72, no. 10, pp. 2254-2260, 1998.

[13] K. A. Korthals and W. D. Wulff, "Traceless stereoinduction in the one-pot assembly of all three rings of hexahydrodibenzopyrans," Journal of the American Chemical Society, vol. 130, no. 10, pp. 2898-2899, 2008.

[14] B. A. D'Sa, P. Kisanga, and J. G. Verkade, " $\mathrm{P}\left(\mathrm{MeNCH}_{2} \mathrm{CH}_{2}\right)_{3} \mathrm{~N}$ : an efficient catalyst for the synthesis of substituted ethyl benzofuran-2-carboxylates," Synlett, no. 5, pp. 670-672, 2001.

[15] D. Bogdal, S. Bednarz, and M. Lukasiewicz, "Microwave induced thermal gradients in solventless reaction systems," Tetrahedron, vol. 62, no. 40, pp. 9440-9445, 2006.

[16] G. Kumaraswamy, G. Ramakrishna, R. Raju et al., "Strategies for the synthesis of fluorinated liquid crystal derivatives from perbromofluoroaromatic systems," Tetrahedron, vol. 66, no. 52, pp. 9814-9827, 2010.

[17] H. F. Guo, H. Y. Shao, Z. Y. Yang et al., "Substituted benzothiophene or benzofuran derivatives as a novel class of bone morphogenetic protein-2 up-Regulators: synthesis, structureactivity relationships, and preventive bone loss efficacies in senescence accelerated mice (SAMP6) and ovariectomized rats," Journal of Medicinal Chemistry, vol. 53, no. 4, pp. 1819-1829, 2010

[18] P. A. Coates, P. Grundt, E. S. J. Robinson et al., "Probes for imidazoline binding sites: synthesis and evaluation of a selective, irreversible $\mathrm{I}_{2}$ ligand," Bioorganic and Medicinal Chemistry Letters, vol. 10, no. 6, pp. 605-607, 2000.

[19] B. Krassowska, U. Markowska, and Z. Eckstein, "Reactions and transformations of deriva-tives of formyl phenoxyalkanocarboxylic acids," Przemysł Chemiczny, vol. 52, no. 11, pp. 741-743, 1973.

[20] N. G. Kundu, M. Pal, J. S. Mahanty, and M. De, "Palladiumcatalysed heteroannulation with acetylenic compounds: synthesis of benzofurans," Journal of the Chemical Society, no. 19, pp. 2815-2820, 1997.

[21] M. W. Khan, M. J. Alam, M. A. Rashid, and R. Chowdhury, "A new structural alternative in benzo[b]furans for antimicrobial activity," Bioorganic and Medicinal Chemistry, vol. 13, no. 16, pp. 4796-4805, 2005.

[22] H. Reinheckel, "Über halogen- und stickstoffhaltige derivate aliphatischer carbonsäuren, I. Die indirekte $\alpha$-bromierung von fettsäureestern," Chemische Berichte, vol. 93, no. 10, pp. 2222-2229, 1960.

[23] T. R. Kelly, A. Szabados, and Y. J. Lee, "Total synthesis of garcifuran B," Journal of Organic Chemistry, vol. 62, no. 2, pp. 428-429, 1997. 
[24] C. R. Edwards, M. J. Readhead, and N. J. Tweddle, "A practical synthesis of 2,3-dihydro-2-benzofurancarboxylic acid: a general route to 2,3-dihydrobenzofurans," Journal of Heterocyclic Chemistry, vol. 24, no. 2, pp. 495-496, 1987.

[25] T. Horaguchi, Ch. Tsukada, E. Hasegawa et al., "Photocyclization reactions. Part 1. Synthesis of dihydrobenzofuranols using photocyclization of 2-alkoxybenzaldehydes, 2' alkoxyacetophenones, 2-formylphenoxy-acetic acids and 2acetylphenoxyacetic acids," Journal of Heterocyclic Chemistry, vol. 28, no. 5, pp. 1261-1272, 1991.

[26] H. M. Colquhoun, D. J. Thompson, and M. V. Twigg, Carbonylation: Direct Synthesis of Carbonyl Compounds, Plenum Press, New York, NY, USA, 1991. 

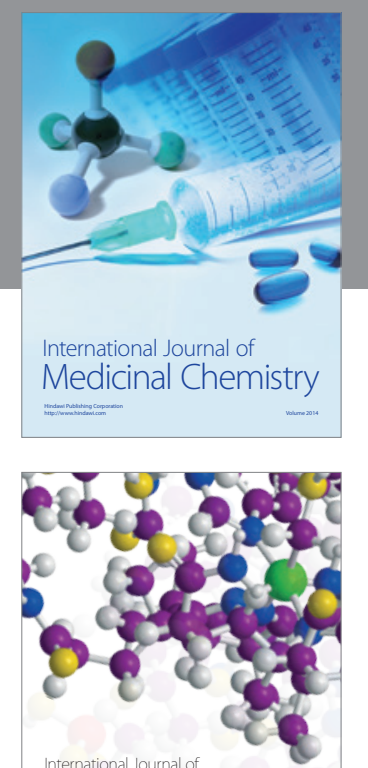

\section{Carbohydrate} Chemistry

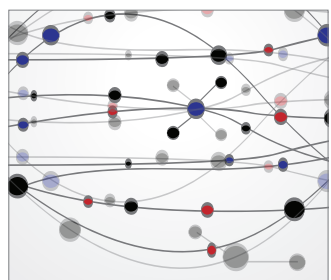

The Scientific World Journal
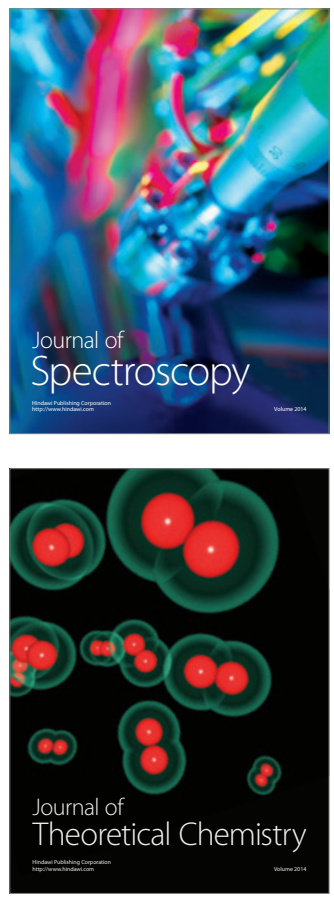
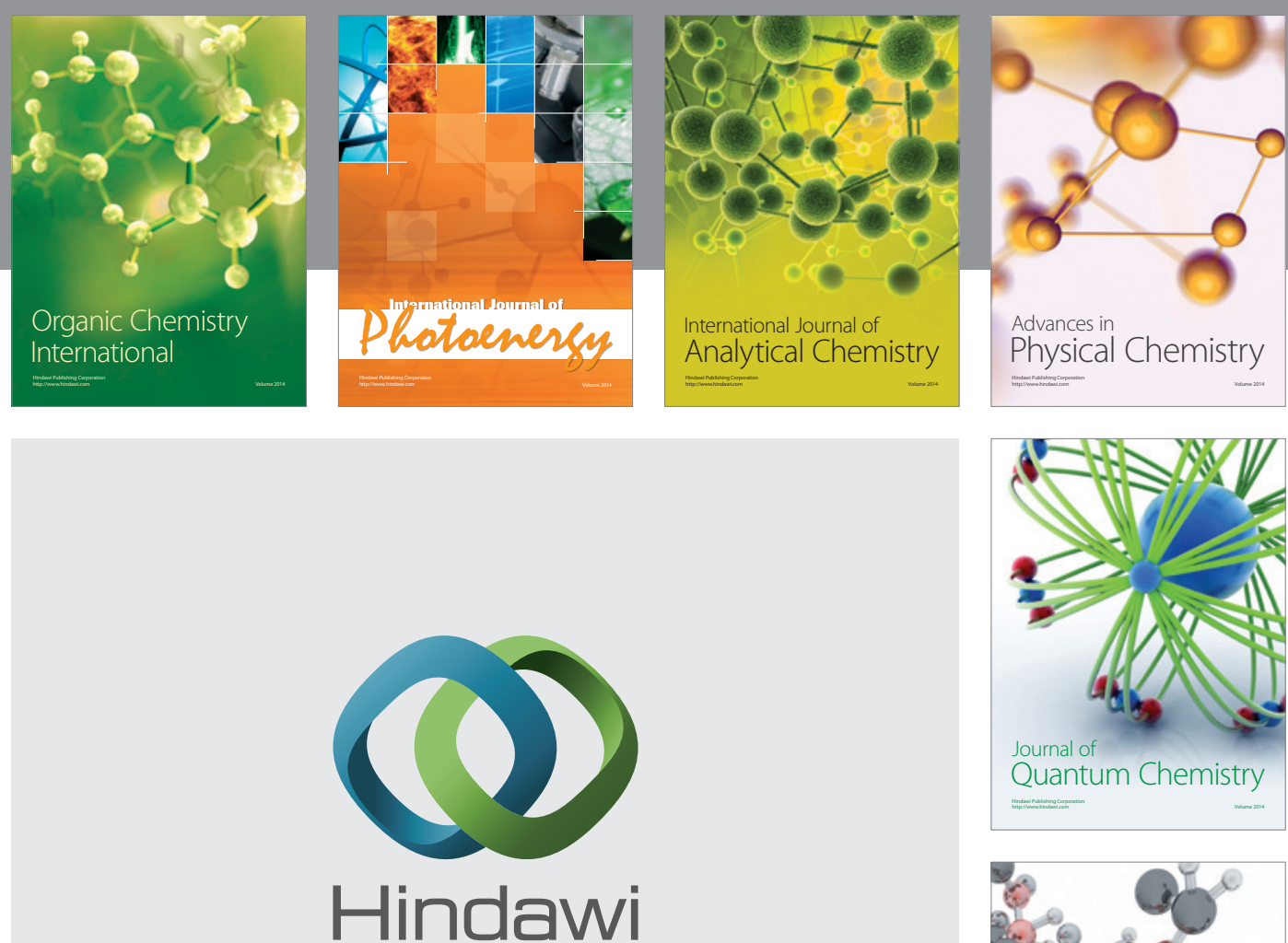

Submit your manuscripts at

http://www.hindawi.com

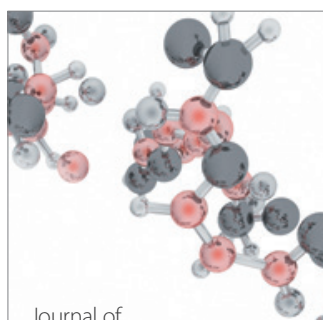

Analytical Methods

in Chemistry

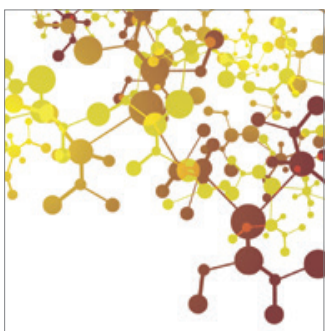

Journal of

Applied Chemistry

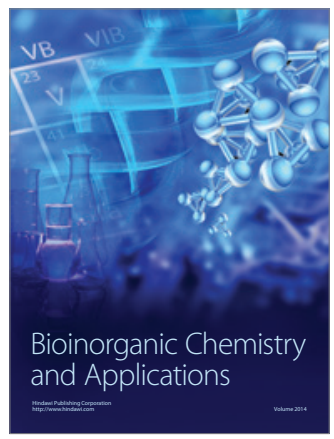

Inorganic Chemistry
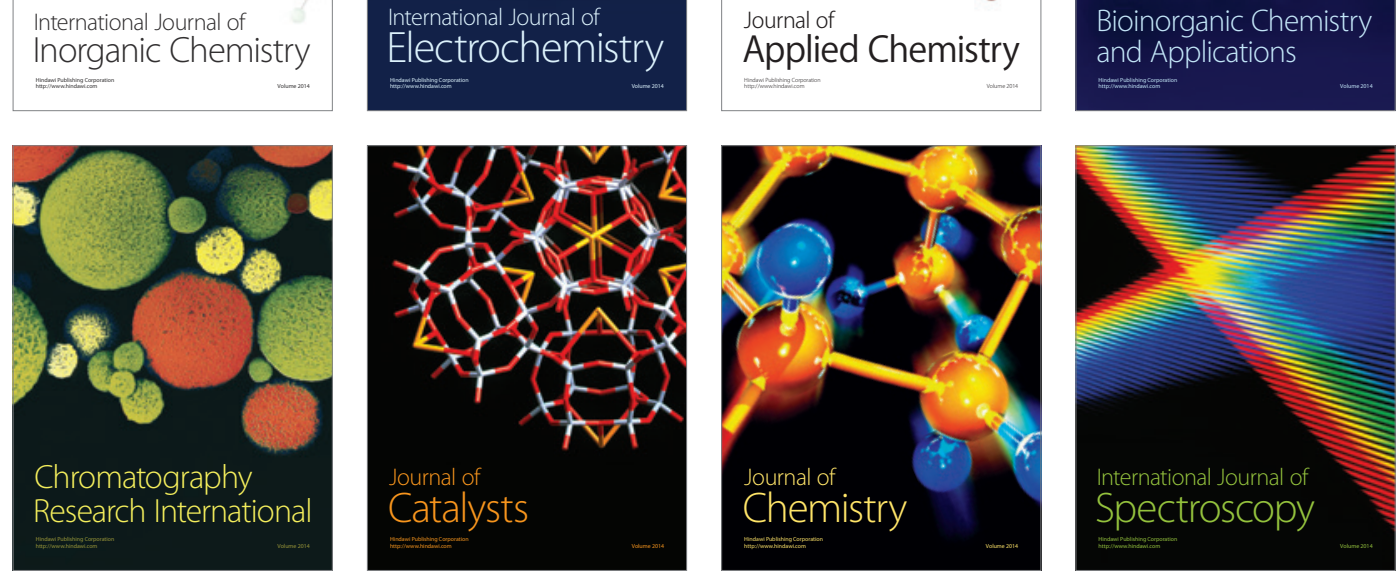